\title{
Retoričko-kritička analiza Poslanice Galaćanima (I)
}

\author{
IVICA ČATIĆ* - MARKo RAJIĆ** \\ UDK: 27-248.48:808 • Izvorni znanstveni rad \\ Primljeno: 12. lipnja 2017. • Prihvaćeno: 23. studenoga 2017.
}

Sažetak: Članak analizira Pavlovu poslanicu Galaćanima po principima retoričkog kriticizma. Ovakav pristup biblijskim tekstovima postao je prominentan u posljednjih četrdesetak godina. Rani zagovornici ove metode djelovali su pod pretpostavkom da je Pavao pisao u skladu s tada poznatim retoričkim priručnicima. U tom smislu, uvod članka propituje odnos Pavlovih poslanica i antičke retorike i literarnog svijeta. Također istražuje mogućnost prihvaćanja šireg koncepta retorike kojega pruža moderno proučavanje te discipline. Uvod članka zaključuju pitanje odnosa retorike i epistolografije, kao i pitanje raspodjele retoričkog čina i njegove primjene na Posla-

${ }^{*}$ Izv. prof. dr. sc. Ivica Čatić, Katolički bogoslovni fakultet u Đakovu Sveučilišta J.J. Strossmayera u Osijeku,

P. Preradovića 17,

31400 Đakovo, Hrvatska, ivicat6@gmail.com

** Marko Rajić, mag. theol., S. Radića 153, Gašinci, 31421 Satnica Đakovačka, Hrvatska, marko-rajic@live.com nicu Galaćanima. Zatim započinje analiza glavnih retoričkih elemenata Poslanice Galaćanima, koja će zbog ograničenosti prostora biti nastavljena u sljedećem članku.

Ključne riječi: Poslanica Galaćanima, retorika, retorički kriticizam, epistolografija.

\section{Uvod}

U posljednja tri desetljeća pojačan je interes za retoričkokritičke pristupe biblijskom tekstu. Ova tendencija pokazuje sve veću svijest o potrebi nadopunjavanja pogleda koje historijski kriticizam pruža na biblijski tekst. Ipak, retorički kriticizam ne bi se trebao shvaćati kao potpuni odmak od interesa kojega je povijesni kriticizam imao za stvarnosti u »pozadini teksta « (poput autora i povijesnih događaja). Jedno je od definirajućih svojstava ovog pristupa nastojanje da se povežu autor, diskurs i čitatelj. ${ }^{1}$ Retorič-

${ }^{1}$ Usp. K. MOLLER, Rhetorical Criticism, u: K. VANHOOZER (ur.), Dictionary for Theological Interpretation of the Bible, Grand Rapids, 2005., 689. 
ki kriticizam primjenjuje se na Novi zavjet, osobito na Pavlove poslanice od sredine sedamdesetih godina dvadesetog stoljeća. U posljednjih nekoliko desetljeća izašao je niz retoričkih studija, budući da je ovaj pristup prihvaćen od sve više tumača i u međuvremenu primijenjen na cijeli spektar novozavjetne literature. ${ }^{2}$

Retorika, prvi i najteži termin za definiranje, gubi preciznost zbog širokog spektra značenja i duge povijesti njezina tumačenja. ${ }^{3}$ Riječi $\gg$ retorika $\ll$ ili $\gg$ retorički $\ll$ koriste se za imenovanje širokog spektra fenomena, uključujući govorništvo, dijelove govora, stratešku uporabu jezika... Autori djela A Companion to Greek Rhetoric kažu kako retorika označava $\gg$ mnoštvo načina bivanja i nastupanja u svijetu $\ll^{4}$. Ako se ne ograniči smisao pojma $\gg$ retorika «, postoji mogućnost shvatiti ga toliko općenito i univerzalno da postane besmislen. ${ }^{5}$ Danas se iz klasičnog i suvremenog proučavanja može iščitati niz načina njegove uporabe. Opseg proučavanja dodatno se proširuje ako se tekstovima koji sebe izričito identificiraju kao dio retoričke tradicije dodaju i oni za koje se smatra kako implicitno sudjeluju u toj tradiciji. Tada, kada se imenica $\gg$ retorika « pretvori u pridjev $\gg$ retorički « i počne promatrati kao određena perspektiva, razni izričiti i implicitni smislovi riječi »retorika « mogu opisati gotovo bilo što. ${ }^{6}$ Ipak, sve antičke definicije pokazuju kako su antički retoričari svoju disciplinu shvaćali usko. Ona nije obuhvaćala sve oblike javne komunikacije, nego ono što se moglo čuti na sudu i političkom skupu. ${ }^{7}$ Retorički kritičari ne smiju zanemariti ni činjenicu da je, po Corbettu, retorika izvorno zamišljena kao umijeće sinteze, izgradnje i komponiranja. Za ljude antike, retorika je sredstvo stvaranja, a ne analize. ${ }^{8}$

Gledano iz moderne perspektive, govorništvo proizašlo iz manualske retorike samo je podsekcija grčko-rimske retorike u cjelini. To je jasno iz činjenice postojanja i drugih načina javnoga obraćanja u helenističkom razdoblju, ${ }^{9}$ što se povremeno priznavalo i u novozavjetnim studijama. F. W. Hughes kaže kako je lako doći do pogrešnog zaključka da je grčko-rimska retorika jedinstven, usko povezan sustav.

\footnotetext{
${ }^{2}$ Usp. isto, 691.

${ }^{3}$ Usp. P. KERN, Rhetoric and Galatians, Cambridge, 2004., 7.

${ }^{4}$ T. PULASKOS, Modern Interpretations of Classical Greek Rhetoric, u: I. WORTHINGTON (ur.), A Companion to Greek Rhetoric, Oxford, 2007. 19.

${ }^{5}$ Usp. J. HAMM, E. SCHIAPPA, Rhetorical Questions, u: Isto, 3.

${ }^{6}$ Usp. isto, 5.

${ }^{7}$ Usp. P. KERN, Rhetoric and Galatians, 14.

${ }^{8}$ Usp. E. CORBETT, Classical Rhetoric for the Modern Student, New York, 1990., 30., citirano prema P. KERN, Rhetoric and Galatians, 22.

${ }^{9}$ Usp. P. KERN, Rhetoric and Galatians, 21.
} 
Svatko tko pokušava sistematizirati retoriku riskira prikazati je unificiranijom i uniformiranijom negoli je bila u stvarnosti. ${ }^{10}$

Wilder je utvrdio kako su se književna djela ranog kršćanstva razlikovala od onih koja su nastala u antičkom poganskom svijetu, te da za njih tradicionalne klasicističke kategorije nisu prikladna mjerila. ${ }^{11}$ On smješta novozavjetne tekstove izvan sfere grčko-rimske retorike, barem u terminima literarne razine, publike i žanra. Istovremeno ispravno uviđa kako kršćanstvo posjeduje vlastiti kod komunikacije, vrijednosne strukture i pogled na svijet koji su često u antitezi s grčko-rimskim oratorijem. Ipak, to ne znači da kršćanska komunikacija nije posjedovala retorički idiom. $^{12}$

Ovo upućuje na zaključak kako jedan manualski retorički žanr ne može opisati cjelinu poslanice. Stoga se nameću dva pitanja: nije li Pavao pod utjecajem drugog modela osim antičkog govorništva, i treba li Poslanicu Galaćanima čitati kao cjelovit tekst, neovisno o provenijenciji? To jest, bi li sinkronično čitanje koje nastoji otkriti temelje argumenata poslanice, koristeći univerzalniji kanon retorike, ponudilo više čitatelju? Kern na oba pitanja odgovara potvrdno. ${ }^{13}$ To znači kako su, odustajanjem od univerzalnog kanona, pojedini autori u opasnosti arbitrarno nametati manualske kategorije tekstu koji je po sebi plod drugih vrsta retorike. Kern smatra kako su jedina čitanja koja tako mogu nastati nužno izobličena i anakronistička. ${ }^{14}$

Gore istaknute činjenice, koje se moraju uzeti u obzir pri razmatranju pojma $\gg r e-$ torike «, nužno ostavljaju posljedice na impostiranje metode njezina istraživanja u konkretnom biblijskom tekstu.

Retoričko-kritička metoda, stoga, više je od puke stilističke analize, socijalnih opisa ili povijesnih rekonstrukcija. Iz raznolikosti shvaćanja pojma $\gg$ retorika « i njezina opsega proizašle su i razne definicije retoričko-kritičkog pristupa. Prema E. Cornelius, gotovo sve definicije ove metode slažu se kako je njezin temeljni cilj »određivanje komunikacijskih funkcija teksta i evaluacija njegovog vjerojatnog učinka $\ll^{15}$.

\footnotetext{
${ }^{10}$ Usp. F. HUGHES, Early Christian Rhetoric and 2 Thessalonians, 1988., 274., citirano prema P. KERN, Rhetoric and Galatians, 40.

${ }^{11}$ Usp. A. WILDER, Early Christian Rhetoric: The Language of the Gospel, 1971., 25, citirano prema P. KERN, Rhetoric and Galatians, 50.

${ }^{12}$ Usp. P. KERN, Rhetoric and Galatians, 52.

${ }^{13}$ Usp. isto, 161.

${ }^{14}$ Usp. isto, 20.

${ }^{15}$ Usp. E. CORNELIUS, Rhetorical Criticism and the Hermeneutics of the New Testament, u: In die Skriflig, 34(2000.)2, 253.-274., ovdje 258.
} 
Sam postupak retoričko-kritičke analize Kennedy je podijelio u šest koraka:

1. Određivanje retoričke cjeline koja je predmet proučavanja.

2. Definiranje retoričke situacije te cjeline.

3. Određivanje glavnog retoričkog problema prisutnog na početku diskursa.

4. Određivanje vrste govorništva kojoj retorička cjelina pripada.

5. Analiza rasporeda materijala s obzirom na njegove subsekcije i argumentativnog učinka njegovih dijelova i stilskih sredstava.

6. Zaključivanje procesa analize, vrednujući uspješnost odgovora na retoričku situaciju i moguće implikacije za govornika i publiku. ${ }^{16}$

Antička pisma važan su izvor za retoričko-kritičku analizu Pavlovih poslanica. U antici se epistolografija nije smatrala dijelom manualske retorike, te je kao disciplina postala značajna tek u srednjem vijeku. Čak je i onda ostala prije svega alat za sintezu i kompoziciju, s ograničenom analitičkom primjenom. ${ }^{17} \mathrm{U}$ antičkom svijetu retorika i epistolarna teorija nisu bile integrirane, te se problemi sastavljanja pisama nisu sustavno obrađivali. Epistolarne konvencije zasigurno su se povremeno preklapale s retoričkima, ali ne mnogo više od onoga što bi se smatralo neizbježnim. ${ }^{18}$ Istovremeno, ljudi antike razlikovali su više vrsta pisama: prijateljska i intimna pisma, epistolarne rasprave i traktate, pismena obraćanja nosiocima vlasti ili određenoj društvenoj skupini itd. ${ }^{19}$ Kod Pavla uočavamo miješanje tih vrsta uslijed čega nastaje specifičan epistolarni žanr: kršćanska poslanica. Pavao u jednom pismu istovremeno izražava svoju bliskost i želju za osobnim susretom, naviješta istinu evanđelja te argumentima pobija tvrdnje svojih protivnika i zablude svojih čitatelja.

U novijoj povijesti istraživanja novozavjetnih poslanica postoje tri pristupa odnosu retorike i epistolografije:

- jedna skupina autora usredotočena je na epistolografske kategorije

- drugi koriste pristup koji naglašava retoriku

- ostali nastoje koristiti retoriku i epistolografiju u jednakom stupnju.

${ }^{16}$ Usp. G. A. KENNEDY, New Testament Interpretation through Rhetorical Criticism, 1984., 10., citirano prema W. RUSSELL, Rhetorical Analysis of the Book of Galatians. Part 2, u: Bibliotheca Sacra, 150(1993.)4, 416.-439., ovdje 416.

${ }^{17}$ Usp P. KERN, Rhetoric and Galatians, 30.

${ }^{18}$ Usp. isto, 31.

${ }^{19}$ Usp. H. KLAUCK, Ancient Letters and the New Testament, Waco, 2006., 185.-187. 
Iz ovakve raznolikosti pristupa E. Cornelius zaključuje kako se ni na ovom području shvaćanje retorike i epistolografije ne smije ograničiti na klasične definicije, nego treba raditi sa širom perspektivom koju pruža moderno istraživanje. ${ }^{20}$

Pitanje podjele retoričkog čina vrlo je složeno te je teško sažeto prikazati njegov razvoj od antike do danas. Razni teoretičari predlažu različit broj dijelova govora, od dva do sedam pa čak i više zbog raznih podsekcija. Neki kao normu uzimaju četiri, a neki pet ili šest. Rhetorica ad Herenium navodi kako govor sadržava ovih šest dijelova:

1. uvod (prooimion; exordium)

2. naracija (prothesis; narratio)

3. raspodjela (divisio, propositio ili partitio)

4. dokazivanje (pistis; confirmatio ili probatio)

5. osporavanje (confutatio; reprehensio)

6. zaključak (epilogus; conclusio ili peroratio). ${ }^{21}$

Većina autora koji se bave retoričko-kritičkom analizom novozavjetnih tekstova služe se varijantama ove klasične podjele retoričkog čina. ${ }^{22}$

Detaljna obrada ovog problema i njegove praktične primjene izlazi izvan opsega našeg rada te se zadržavamo na samo nekoliko primjedbi. Iz svega što je do sada rečeno o naravi retorike jasno je kako treba izbjegavati svaki pokušaj uklapanja cjeline poslanice u neki specifični manualski sustav. Premda neki njezini dijelovi odgovaraju manualskim definicijama, drugi se samo po analogiji mogu zvati terminima iz manuala. Za takve dijelove u ovom radu rabimo alternativne termine. Tako se, po Meynetu, umjesto termina narratio, probatio i exortatio, koriste pojmovi narativne, demonstrativne i parenetske sekcije. ${ }^{23}$ Ključ za demarkaciju između ovih sekcija promjena je u prevladavajućem retoričkom »žanru « (pripovijedanje, dokazivanje, etički nagovor). Svaka od tih sekcija ima svoje podcjeline (narativne epizode, argumenti, specifični moralni problemi). Ovakav pristup promatra poslanicu prije svega kao samostalnu i originalnu retoričku i literarnu cjelinu, a ne kao primjenu nekog postojećeg retoričkog modela.

\footnotetext{
${ }^{20}$ Usp. E. CORNELIUS, Rhetorical Criticism and the Hermeneutics of the New Testament, 256.

${ }^{21}$ Usp. R. LANHAM, A Handlist of Rhetorical Terms, Berkeley, 1991., 171.

${ }^{22}$ Usp. P. KERN, Rhetoric and Galatians, 107.-108.

${ }^{23}$ Usp. R. MEYNET, Treatise on Biblical Rhetoric, Boston, 2012., 53.
} 
U tom smislu, naš rad Poslanicu Galaćanima obrađuje u sljedećem rasporedu:

1, 1-5 Epistolarni preskript

1, 6-10 Exordium

1, 11 - 2, 14 Narativna sekcija poslanice

1, 11-24 Pavlov život u židovstvu i početak apostolskog djelovanja

2, 1-10 Jeruzalemska epizoda naracije

2, 11-14 Antiohijska epizoda naracije

2, 15 - 4, 31 Demonstrativna sekcija poslanice

2, 15-21 Propositio

3, 1-18 Soteriološka nemoć Zakona i narav Božjih obećanja

3, 19 - 4, 11 Temporalna i etnička funkcija Zakona u povijesti spasenja

4, 12-20 Emotivna digresija

4, 21-31 Alegorija Sara/Hagara

5, 1 - 6, 10 Parenetska sekcija poslanice

5, 1-12 Nagovor protiv obrezanja

$5,13-24$ Nagovor na život po Duhu

6, 1-9 Neke praktične implikacije života po Duhu

6, 11-18 Pavlov vlastoručni zaključak.

Razilaženja autora o demarkaciji pojedinih cjelina i njihovoj retoričkoj naravi bit će naznačena pri njihovoj obradi.

\section{Epistolarni preskript (Gal 1, 1-5)}

Tradicionalno, antičko pismo sadržavalo je tri elementa u svom prologu: superscriptio (pošiljatelj pisma, 1, 1-2a), adscriptio (primatelj pisma, 1, 2b) i salutatio (pozdrav, 1, 3-5). U uvodnim pozdravima svojih poslanica Pavao obično slijedi navedenu shemu, ali redovito pošiljatelja i primatelja opisuje preciznijim terminima.

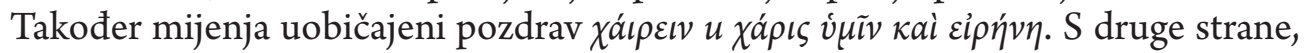
Pavao nikad ne koristi nepromjenjivu šablonu za otvaranje poslanica, nego ju prilagođava pojedinim prilikama, što je slučaj i u ovoj poslanici. ${ }^{24}$

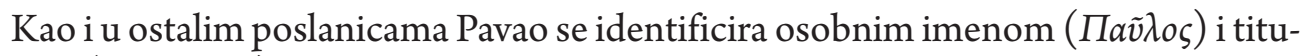

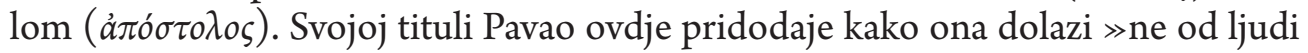
ni po kojem čovjeku, nego po Isusu Kristu i Bogu Ocu koji ga uskrisi od mrtvih «.

${ }^{24}$ Usp. D. F. TOLMIE, A Rhetorical Analysis of The Letter to The Galatians, doktorska teza na sveučilištu Free State, Bloemfontain, 2004., 40. 
To čitatelju odmah daje do znanja kako će izvor i vjerodostojnost njegovog apostolstva biti važno pitanje. To je zaista tako, osobito u narativnom dijelu poslanice. ${ }^{25}$ Po svom običaju, Pavao spominje i supošiljatelje. Za razliku od drugih poslanica, ovdje ne spominje nikoga poimence. Umjesto toga, kao supošiljatelje navodi $\gg$ svu braću koja su sa mnom«. Retorička funkcija ovih riječi stvoriti je sliku grupe ljudi koja stoji uz Pavla, podržava ga i potvrđuje sadržaj poslanice. ${ }^{26}$ Prvi dio salutatia tipično je pavlovski $(1,3)$, te inkorporira tradicionalne grčke i hebrejske elemente u specifično kršćanski pozdrav. Elementi kojima Pavao proširuje pozdrav uvijek su srž poruke koju naviješta u pojedinoj poslanici. U ovom slučaju naglašava kako je, po volji Oca Nebeskoga, Kristova otkupiteljska smrt temelj iskupljenja iz sadašnjeg opakog svijeta. Doksološki zaključak pozdrava $(1,5)$ apel je čitateljima neka prihvate Pavlova stajališta jer su ona u skladu s onim što sve kršćanske zajednice ispovijedaju i slave u svojim bogoslužjima. Time Pavao pokazuje kako on nije osoba koja izvrće objavljenu istinu. ${ }^{27}$

\section{Exordium (Gal 1, 6-10)}

Glavna svrha antičkog exordiuma jest osiguravanje pažnje publike, no Pavao ovdje čini i više od toga. On diskreditira svoje protivnike služeći se govorničkim terminima i izražava svoje razočaranje u Galaćane zbog njihova prijelaza na protivničku stranu. ${ }^{28}$ Većina egzegeta odmah ističe izostanak uvodne doksologije. Za Pavla ona nikada nije sama sebi svrhom, nego je integralni dio poslanice koji najavljuje teme i ton rasprave. Izostanak takve doksologije u ovoj poslanici smjesta je uočljiv i vjerojatno je znak prijekora. ${ }^{29}$

Umjesto doksologije, šesti redak donosi ironično izricanje cause praćeno čuđenjem što su Pavlovi čitatelji tako brzo napustili njegov nauk..$^{30}$ Ovo izražavanje čuđenja J. L. White prepoznao je kao epistolarnu konvenciju čija je svrha kuđenje čitatelja i mjesto joj je na samom početku tijela pisma. Papirusi otkrivaju kako na tom mjestu pošiljatelj ili zahvaljuje božanstvu na dobročinstvu, ili izražava čuđenje zbog

\footnotetext{
${ }^{25}$ Usp. L. CRANFORD, A Rhetorical Reading of Galatians, URL: http://cranfordville.com/Cranfordville/GalRead.pdf (27. II. 2014.)

${ }^{26}$ Usp. D. F. TOLMIE, A Rhetorical Analysis of The Letter to The Galatians, 43.

${ }^{27}$ Usp. L. CRANFORD, A Rhetorical Reading of Galatians, URL: http://cranfordville.com/Cranfordville/GalRead.pdf (27. II. 2014.)

${ }^{28}$ Usp. H. D. BETZ, The literary composition and function of Paul's letter to the Galatians, u: New Testament Studies, 21(1975.)3, 353.-379., 362.

${ }^{29}$ Usp. P. T. O’BRIEN, Introductory Thanksgivings in the Letters of Paul, 1977., 261.-263., citirano prema D. F. TOLMIE, A Rhetorical Analysis of The Letter to The Galatians, 46.

${ }^{30}$ Usp. W. RUSSELL, Rhetorical Analysis of the Book of Galatians. Part 2, 419.
} 
nečega što je primatelj učinio. Brojni primjeri pokazuju kako je to čuđenje zapravo ironično i kako za svrhu ima kuđenje čitatelja zbog nekoga propusta. ${ }^{31}$ Pavlov je prijekor Galaćanima vrlo oštar: čudi se što su Galaćani tako brzo postali »otpadnici«. Istovremeno im u prijekoru očituje pravu narav njihovog čina: Galaćani su napustili »onoga koji ih je pozvao«. Ova se fraza može dvosmisleno tumačiti. U pravilu, Pavao ovim izrazom misli na Boga, ali bi mogao misliti i na sebe jer postoji bliska veza između njegovog navještaja i Božjeg poziva Galaćanima. Schlier kaže kako su, iz perspektive Galaćana, Božji poziv i Pavlova kerigma u biti jedno te isto. ${ }^{32}$

U 1, 6-7 Pavao skreće pozornost Galaćana na svoje protivnike i njegova retorička strategija od kuđenja prelazi u diskreditaciju. Diskreditiranje je protivnika raširen fenomen u ranokršćanskoj epistolografiji mediteranskog područja. U ovom slučaju Pavao diskreditaciju postiže na sljedeće načine:

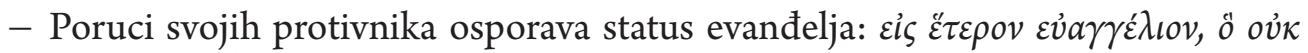
$\ddot{\varepsilon} \sigma \tau \iota v a ̊ d \lambda \lambda_{o}(1,6-7 \mathrm{a})$. Iako njihovu poruku isprva naziva evanđeljem, Pavao se smjesta ispravlja. Time želi prenijeti misao kako je evanđelje njegovih protivnika evanđelje druge vrste, različito od istinskog. Zato se ni ne smije smatrati evanđeljem.

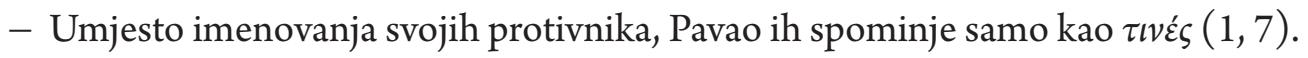
To je bila uobičajena praksa u antici. Cilj je ostaviti dojam kako su neistomišljenici malobrojni i beznačajni, a imena im nisu vrijedna spomena.

- Pavao bira riječi vrlo negativnih konotacija. Optužuje svoje protivnike za uznemiravanje Galaćana i mijenjanje evanđelja. Ključni termini poput $\tau \alpha \rho a ́ \sigma \sigma o v \tau \varepsilon \varsigma$

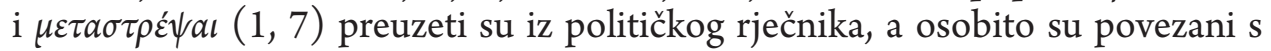
pitanjem zajednice i lojalnosti. Pavao ovakvim izborom riječi apelira na jedinstvo koje je istinsko evanđelje stvorilo među Galaćanima, a kojemu sada prijeti nazovi-evanđelje nekih prevratnika. ${ }^{33}$

Nakon što je prekorio Galaćane i diskreditirao svoje protivnike, u 1, 8 tvrdi kako su Galaćani od njega primili jedino istinsko evanđelje i izriče prokletstvo na svakoga tko bi se usudio naviještati nešto njemu suprotno. Time stvara antitezu između sebe, apostola Isusa Krista, i svojih protivnika, uznemiritelja kojima prijeti prokletstvo. ${ }^{34}$ Izricanje prokletstva jedno je od najučinkovitijih antičkih retoričkih

${ }^{31}$ Usp. J. L. WHITE, Body of the Greek Letter, 1972., 33.-36., citirano prema P. KERN, Rhetoric and Galatians, 95.

${ }^{32}$ Usp. H. SCHLIER, Der Brief an die Galater, 1971., 38., citirano prema D. F. TOLMIE, A Rhetorical Analysis of The Letter to The Galatians, 47.

${ }^{33}$ Usp. W. RUSSELL, Rhetorical Analysis of the Book of Galatians. Part 2, 419.

${ }^{34}$ Usp. isto, 420. 
sredstava. Dvostruko prokletstvo koje Pavao izriče u redcima 9-10 vrlo je pažljivo strukturirano. ${ }^{35}$ Betz smatra kako način na koji ga Apostol izriče ukazuje kako samo ponavlja prokletstvo izrečeno nekom ranijom prilikom. ${ }^{36}$ Veoma učinkovito koristi dvostruko prokletstvo i tako postiže nekoliko ciljeva. Kao prvo, nastavlja diskreditaciju svojih protivnika započetu u prethodnom retku. Drugo, neizravno za sebe prisvaja božanski autoritet osobe ovlaštene proglašavati prokletstva. Prokletstvo istovremeno služi i kao neizravno upozorenje Galaćanima. Iako je izrečeno tako da se odnosi na one koji propovijedaju »evanđelje koje to nije «, njegov je domet širi. Ako Galaćani pristanu uz poruku Pavlovih suparnika, bit će dionici njihove propasti. Konačno, uključujući i sebe pod prokletstvo, Apostol prenosi misao da nijedan čovjek sam po sebi ne može određivati kriterij istinitosti evanđelja. Evanđelje je važnije od svakog čovjeka, pa i od samog Pavla. Ono ima vlastitu egzistenciju i neovisno je o bilo kojem ljudskom autoritetu. ${ }^{37}$

Adams smatra kako Pavao desetim retkom najavljuje početak svoje autobiografske pripovijesti. U njemu pomiče fokus s povijesti Galaćana na vlastitu povijest, kojom želi dokazati tvrdnju kako je proklet onaj koji naviješta evanđelje drukčije od onoga kojeg su Galaćani primilii. ${ }^{38}$ Distinkcija ljudi i Krista odmah na početku sljedeće sekcije $(1,11)$ dozvat će u sjećanje Pavlov uvod u kojem je zanijekao da njegovo apostolstvo dolazi $\gg$ od ljudi « ili $\gg$ po nekom čovjeku «, nego dolazi $\gg$ po Isusu Kristu i Bogu Ocu koji ga uskrisi od mrtvih $\ll(1,1)$. Ovu podjelu između ljudskog i božanskog autoriteta sada preslikava na kronologiju svoga života. Deseti redak opisao je promjenu koja se dogodila u njegovu životu. On je sada sluga Kristov upravo zato što njegovo evanđelje nije $\gg$ po nekom čovjeku $\ll{ }^{39}$

\section{Narativna sekcija poslanice (Gal 1, $11-2,14)$}

Betzova analiza narativnog dijela poslanice oslanja se na elemente klasičnog antičkog narratia, čija je svrha prezentirati činjenice koje se tiču slučaja kako bi se utvrdila govornikova vjerodostojnost. ${ }^{40} \mathrm{On}$ misli kako riječ $\gamma v \omega \rho i \zeta \varepsilon v v$ u retku 11 ukazuje da Pavao želi podsjetiti Galaćane na stvari koje su im već poznate, samo fingirajući govor o nečemu novom. ${ }^{41}$ Dok gotovo svi tumači priznaju kako se radi o jasno

\footnotetext{
${ }^{35}$ Usp. D. F. TOLMIE, A Rhetorical Analysis of The Letter to The Galatians, 49.

${ }^{36}$ Usp. H. D. BETZ, The literary composition and function of Paul's letter to the Galatians, 363.

${ }^{37}$ Usp. D. F. TOLMIE, A Rhetorical Analysis of The Letter to The Galatians, 49.

${ }^{38}$ Usp. R. ADAMS, The Israel of God. The Narrative Rhetoric of Paul's Letter to the Galatians, doktorska teza na sveučilištu Emory, Atlanta, 2012., 213.

${ }^{39}$ Isto, 214.

${ }^{40}$ Usp. H. D. BETZ, The literary composition and function of Paul's letter to the Galatians, 365.

${ }^{41}$ Usp. isto, 366.
} 
određenoj narativnoj cjelini unutar poslanice, ipak ne dijele svi Betzovo mišljenje da se radi o narratiu u klasičnom manualskom smislu. Glavni prigovor klasificiranju 1, $11-2,24$ kao narratio jest što bi se u tom slučaju degradirala argumentativna vrijednost ovog dijela poslanice, budući da se klasični narratio smatrao pukom pripremom za »pravo« dokazivanje koje tek slijedi. Prema ovom viđenju, Pavao već pokušava nešto dokazati u 1,11 : božanski izvor njegova poslanja, to jest božansku autorizaciju za svoje propovijedanje. $U$ tom smislu, $1,11-2,21$ ima važnu stratešku ulogu: događaji kojih se Pavao prisjeća dokaz su njegovih tvrdnji o sebi, svom identitetu i poruci. To je čest zaključak egzegeta koji ne pokušavaju poslanicu na silu uklopiti u određeni antički retorički model. Primjerice, Burton smatra kako je cilj 1, $11-2,11$ »dokazivanje apostolove neovisnosti o svakom ljudskom autoritetu i njegovog iskustva izravne Kristove objave $\ll{ }^{42}$.

Pavlov slučaj zahtijeva dugačko navođenje činjenica jer mora prikazati cijelu svoju povijest. Stoga započinje svojim rođenjem jer je njegovo židovsko podrijetlo relevantno za argumente koje će iznositi kasnije (Usp. 2, 14-16; 3, 23-25; 4, 24-26). Zatim prikazuje povijest spora u manjim epizodama, koje čitatelj mora poznavati kako bi razumio sadašnju situaciju. Njegova pripovijest ugrubo se može podijeliti na tri dijela. Prvi dio $(1,13-24)$ pokriva dugačak vremenski period i podijeljen je u nekoliko podsekcija. Srednji je dio nešto kraći i izvještava o takozvanom Jeruzalemskom saboru (2, 1-10). Zadnji dio opisuje samo jednu kratku epizodu, konflikt $\mathrm{s}$ Kefom u Antiohiji (2, 11-14). Na taj način Pavao uspijeva prikazati dugu povijest kontroverze, izričući ono bitno i ispuštajući sve nevažne događaje. Izvještaj je kratak, ali ne i pretjerano koncizan. Radi se o živoj i dramatičnoj naraciji, ali bez nepotrebne kićenosti i jezičnih ornamenata. ${ }^{43}$ Tako će Pavao iznijeti božanski izvor svog poziva te evanđelja koje mu je povjereno i koje je uspješno branio kako u jeruzalemskoj tako i u antiohijskoj epizodi.

\subsection{PAVlov Život u ŽIDovstVu I PoČEtaK Apostolskog DJElovanja (GAL 1, 13-24)}

Granice retoričke jedinice 1, 13-24 jasno su definirane paralelnim izjavama u redcima 13 i 23-24. Riječi kojima Pavao započinje svoje prisjećanje odraz su riječi kojima zajednice u Judeji sažimaju vlastito prisjećanje njegove povijesti. Kao što su Galaćani čuli za Pavlovo proganjanje i pustošenje Crkve, tako su i Judejci čuli da njihov nekadašnji progonitelj navješćuje vjeru koju je nekoć pustošio. ${ }^{44}$

\footnotetext{
${ }^{42}$ W. BURTON, A Critical and Exegetical Commentary on the Epistle of the Galatians, 1921., 35., citirano prema D. F. TOLMIE, A Rhetorical Analysis of The Letter to The Galatians, 54.

${ }^{43}$ Usp. H. D. BETZ, The literary composition and function of Paul's letter to the Galatians, 367.

${ }^{44}$ Usp. R. ADAMS, The Israel of God, 216.
} 
Pavao predstavlja životni put prvo u negativnim terminima svoga djelovanja protiv $\gg$ Crkve Božje « $(1,13)$, a zatim terminima povezanim s njegovim napretkom u židovstvu u usporedbi sa suvremenicima $(1,14)$. Naracija postupno napreduje od Pavlova ponašanja do reputacije koja iz njega proizlazi. Proganjanje i pustošenje Crkve vodilo je do njegovog stalnog napredovanja u židovstvu. Pavao povezuje progone s pretjeranom revnošću ( $\pi \varepsilon \rho \iota \sigma \sigma o \tau \dot{\varepsilon} \rho \omega \varsigma \zeta \eta \lambda \omega \tau \eta \dot{\varsigma} \dot{v} \pi \dot{\alpha} \rho \chi \omega v)$, a spominjanje vršnjaka ostavlja dojam kako je progon bio sredstvo ugađanja drugima, što opisuje kao temelj svog prijašnjeg života $(1,10)$. Njegovo napredovanje u židovstvu obrnuto je proporcionalno napretku evanđelja, i to mu osigurava priznanje kod Židova. ${ }^{45}$ Ovo prisjećanje postavlja antitezu između Židova Pavla i $\dot{\varepsilon} \kappa \kappa \lambda \eta \sigma i ́ a ~ \tau o \tilde{v} \theta \varepsilon o \tilde{v}$ (koja odgovara starozavjetnoj קהל יהוה). U nastojanju da bude pobožan i vjeran sluga Božji, ironično, radio je protiv Boga. Pavao implicira kako se takav čovjek nikad ne bi promijenio zbog ljudskog utjecaja. Jedini način da do toga dođe jest putem Božjega zahvata. ${ }^{46} \mathrm{U}$ ovom odjeljku uočljiva je česta upotreba hiperbole. Pri opisivanju proganjanja Crkve, Pavao se koristi riječima $\kappa a \theta^{\prime} \dot{v} \pi \varepsilon \rho \beta o \lambda \eta \dot{v}$, koje ukazuju na prelazak preko granice onoga što se smatra normalnim ponašanjem. Osim »proganjanja « ( $\dot{\varepsilon} \delta i \omega \kappa o v)$, koristi i riječ $\dot{\varepsilon} \pi o ́ \rho \theta o v v$. Radi se o vrlo oštrom izrazu koji izriče njegovo djelovanje kao pokušaj potpunog uništenja Crkve. Četrnaesti redak očituje sličnu tendenciju preuveličavanja. Apostol opisuje svoj napredak u židov-

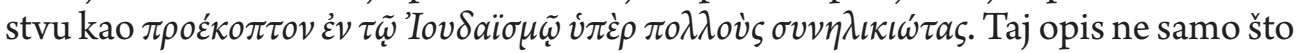
označava nadilaženje suvremenika nego i nosi snažan naglasak superiornosti. Pavao opisuje svoje ponašanje kao pretjeranu revnost za otačke tradicije. Iako same

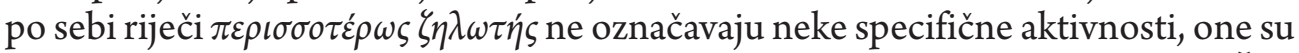
vrlo snažan opis čovjeka čijim životom potpuno dominiraju otačke predaje. Želi prijašnjeg sebe prikazati kao fanatika koji se nikada ne bi promijenio da ga Bog nije zahvatio, zato svoj prijašnji život opisuje kao potpunu predanost židovstvu. ${ }^{47}$

Božanski motiv javlja se kada mu Bog odlučuje objaviti svoga Sina i njegovo poslanje. Pavao dodaje kako se o tom događaju nije konzultirao s ljudskim autoritetima, nego je otišao u Arabiju. Čini se kako u ovom dijelu naracije ulaže velik napor u distanciranju od prijašnjeg načina života. Suprotnost njegova starog i novoga života jest suprotnost dvaju autoriteta, božanske objave i očinskih predaja. Što se tiče apostola, nakon obraćenja im nije bio konkurencija niti se za njih raspitivao (za razliku od svog ponašanja u židovstvu), nego ih je ignorirao. Njegov odlazak u Arabiju označava prekid s ljudskom tradicijom i autoritetom. Kontrast je između starih i novih odnosa jasan: dok su staroga Pavla obilježavali ljudski odnosi s predcima i

\footnotetext{
${ }^{45}$ Usp. isto, 221.

${ }^{46}$ Usp. D. F. TOLMIE, A Rhetorical Analysis of The Letter to The Galatians, 60.

${ }^{47}$ Usp. isto, 61.
} 
suvremenicima, novi je tako usredotočen na Boga da još nema nikakav odnos $\mathrm{s}$ drugim apostolima. ${ }^{48}$ Kroz čitavu naraciju nastoji naglasiti kako djeluje neovisno o ostalim vođama rane Crkve. Dobiva se snažan dojam kako »ljudi « iz 1, 1.11 nisu općenit pojam, nego su konkretizirani u osobi Petra i ostalih apostola. Vrlo je vjerojatno kako su se Pavlovi protivnici u Galaciji pozivali na autoritet jeruzalemskih vođa, nastojeći tako potkopati njegov autoritet. Kao odgovor, Apostol se poziva na božansko poslanje kao najbolji argument koji može pružiti Galaćanima. Božanski izvor njegovog poslanja vidi se u svim epizodama njegova apostolskog djelovanja: u pozivu i obraćenju (1, 13-17), prvom odlasku u Jeruzalem nakon obraćenja (1, 18-19), kasnijem odnosu sa zajednicama u Judeji (1, 20-24), sudjelovanju na Jeruzalemskom saboru (2,1-10) i, napokon, konfrontaciji s Kefom u Antiohiji (2, 11-14). ${ }^{49}$

Pavao se zatim okreće svom prvom posjetu Jeruzalemu. U kontekstu retoričke situacije Poslanice Galaćanima, odnos s Jeruzalemom osjetljiva je tema jer su se njegovi protivnici gotovo sigurno pozivali na autoritet apostolskih prvaka. Zbog te činjenice i zbog važnosti Jeruzalema u ranom kršćanstvu Apostol ne može, vjerojatno i ne želi, ignorirati to pitanje. Ne može ga ignorirati ni zbog činjenice da ga je do trenutka pisanja poslanice posjetio dva puta. U njegovoj argumentativnoj strategiji Jeruzalem nema ulogu koju ima kod njegovih protivnika. Za njih je činjenica da mogu povezati (ili barem pokušati povezati) svoj autoritet s Jeruzalemom jedan od temeljnih argumenata. Pavlu nešto drugo već zauzima mjesto ključnog argumenta: božansko podrijetlo njegovog poslanja. Zbog toga Jeruzalem u njegovom argumentu mora imati drukčiju ulogu. U redcima $15-17$ već je ustvrdio kako je njegova prva reakcija na poziv bila odlazak u Arabiju, ne u Jeruzalem. Za njega je to dokaz kako njegovo poslanje ne ovisi o ljudskom autoritetu. ${ }^{50}$

Apostol navodi kako je svrha njegova prvog posjeta Jeruzalemu bila i $\sigma \tau \rho \rho \tilde{\eta} \sigma a \iota$

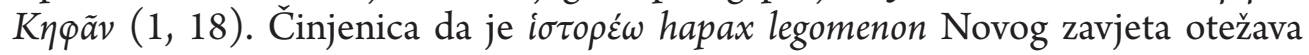
određivanje točnog značenja tog izraza. Većina tumača suglasna je kako označava »upoznati se sa « (eng. to get aquainted with; njem. Kennenzulernen), bez ikakvih konotacija razmjene informacija. Što god se dogodilo pri susretu s Kefom, ostaje skriveno iza ovoga glagola kojega Pavao, očito je, namjerno bira kako bi odbacio mogućnost da se njegov posjet Jeruzalemu tumači kao traženje odobrenja ili poduke od Kefe i/ili drugih apostola. Tvrdi kako tijekom svoga kratkog posjeta nije bio

\footnotetext{
${ }^{48}$ Usp. P. KOPTAK, Rhetorical Identification In Paul's Autobiographical Narrative, URL: http://www. religiononline.org/showarticle.asp?title=4 (27. II. 2014.)

${ }^{49}$ Usp. L. CRANFORD, A Rhetorical Reading of Galatians, URL: http://cranfordville.com/Cranfordville/GalRead.pdf (27. II. 2014.)

${ }^{50}$ Usp. D. F. TOLMIE, A Rhetorical Analysis of The Letter to The Galatians, 67.
} 
u kontaktu ni s jednim drugim nositeljem jeruzalemske tradicije. Iznimka je Jakov,

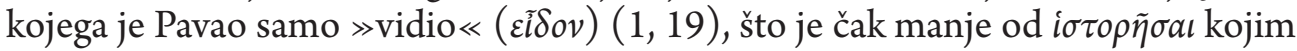
opisuje svoj susret $\mathrm{s}$ Kefom. Vjerodostojnost svoje izjave potvrđuje svečanom za-

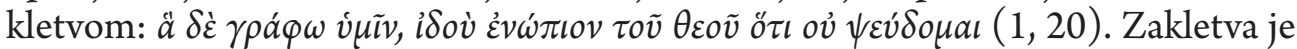
vrlo snažno retoričko sredstvo i činjenica da je Pavao koristi u ovom trenutku ukazuje na to kako je njegovu verziju događaja u Jeruzalemu slušateljstvo/čitateljstvo Poslanice moralo doživjeti kontroverznom. Dakako, zakletva bi se mogla koristiti i kao sredstvo za prikrivanje laži. U ovom slučaju tu mogućnost isključuje kontekst: kao bogobojazni apostol, Pavao se zasigurno ne bi lažno zaklinjao. Iz njegove zakletve očito je da očekuje kako će Bog kazniti one koji se njome krivo koriste. Tako će ona pojačati njegovu vjerodostojnost i demonstrirati iskrenost. ${ }^{51}$

Nakon tog posjeta Pavao se vraća na poganski teritorij $(1,21)$. Naglašava kako je u Judeji i dalje bio nepoznat, Crkve ga nisu poznavale ni po viđenju $(1,22)$. Iako želi naglasiti svoju fizičku udaljenost od apostola, istovremeno naglašava njihov zajednički cilj. Crkve su čule (možda od Kefe i Jakova) kako sada propovijeda vjeru koju je nastojao uništiti. Rascjep između Pavla i Crkve premošten je Božjom objavom Krista progonitelju. Izvori podjele (Krist i evanđelje) postali su izvori jedinstva. Iako Apostol ljude iz tih zajednica ne poznaje osobno, koristi princip identifikacije kako bi u narativu stvorio vezu s njima. ${ }^{52}$

\subsection{JeRUZALEMSKa EPIZODA NARACIJE (GAL 2, 1-10)}

U prvom dijelu naracije Pavao je ustvrdio kako je njegovo djelo među poganima naišlo na odobravanje. U drugom dijelu $(2,1-10)$ tomu pridodaje kako je evanđelje koje je propovijedao bilo slobodno od obrezanja. Retorička situacija slična je onoj u 1, 13-24: Apostolov osobni osvrt na događaje iz prošlosti koji služe kao dokaz, imajući u vidu situaciju u Galaciji. Iz opisa svrhe njegova drugog posjeta Jeruzalemu jasno je kako se naglasak pomaknuo na sadržaj njegova evanđelja. ${ }^{53} \mathrm{U}$ ovoj sceni narativna brzina prilično se usporava u usporedbi s 1, 16-24. Drugi dolazak u Jeruzalem najavljen je sažimanjem četrnaest godina u jednu kratku tranziciju. Ovaj prijelaz na čitatelja ostavlja dojam kako su događaji iz 1, 21-24 trajali i dalje. To jest, čitatelj bi pretpostavio kako je tih četrnaest godina Pavao bio daleko od Jeruzalema, a njegova je reputacija ipak rasla i doprinosila proslavljanju Boga. U Jeruzalem ne putuje sam. Uzlazi zajedno s Barnabom i vodi sa sobom Tita, osobe za koje pretpo-

\footnotetext{
${ }^{51}$ Usp. isto, 68.

${ }^{52}$ Usp. P. KOPTAK, Rhetorical Identification In Paul's Autobiographical Narrative, URL: http://www. religiononline.org/showarticle.asp?title=4 (27. II. 2014.)

${ }^{53}$ Usp. D. F. TOLMIE, A Rhetorical Analysis of The Letter to The Galatians, 73.
} 
stavlja kako ih čitateljstvo poznaje. Obojica imaju ključnu ulogu u raspletu pripovijesti, ali je njihova funkcija isprva nejasna. ${ }^{54}$

Dok Pavao ide u Jeruzalem, čitatelj je svjedok konflikta između objave po kojoj uzlazi ondje i ljudske reputacije koju nastavlja prepoznavati u apostolima. Ta tenzija između božanskih i ljudskih sila i dalje je u samom centru njegova argumenta. ${ }^{55}$ Izvještava kako je uzašao u Jeruzalem i susreo se s apostolima. Spominjanje objave u 2, 2 pokazuje krajnju Pavlovu odanost Bogu, ne jeruzalemskim apostolima. Ipak, priznaje kako im je morao izložiti svoje evanđelje zbog nekog problema koji bi mogao učiniti njegov trud uzaludnim. Svoj susret s apostolima prikazuje kao susret jednakih, zamišljen kao sredstvo postizanja konsenzusa o evanđelju slobodnom od obrezanja. Apostol navodi dva značajna zaključka sastanka: Tit nije bio prisiljen obrezati se i njegovo je djelo među poganima toplo primljeno. ${ }^{56}$

U četvrtom retku prvi put spominje važan element svog evanđelja. Radi se o $\dot{\eta}$ $\dot{\varepsilon} \lambda \varepsilon v \theta \varepsilon \rho i ́ a$, slobodi. Sloboda u Kristu jedan je od važnijih elemenata njegove poruke. Iako je ovdje ne predstavlja preciznijim terminima, njezin kontrast u odnosu na pokušaje lažne braće da ih zarobe (iva i $\mu \tilde{a} \varsigma \kappa a \tau a \delta o v \lambda \omega ́ \sigma o v \sigma v v)$ sugerira kako misli na slobodu od vršenja Zakona. ${ }^{57}$ Manjak detalja o identitetu lažne braće poziva čitatelje da tipološki odgovore na ovu scenu: dok Pavao predstavlja situaciju Galaćanima, neka dozovu u sjećanje izazove od strane vlastite »lažne braće «. Galaćani, koji žive u slobodi zbog evanđelja koje im je Apostol navijestio, u napasti su ograničiti slobodu zahtjevima židovskog Zakona. Iako još nije izričito načinio vezu između jeruzalemske lažne braće i galacijskih uznemiritelja, Pavlova bi publika trebala prepoznati kako ova priča nije puki izvještaj o njegovim postupcima u prošlosti. Nakon što su se javili u 2, 4, lažna braća iščezavaju u 2, 6, odigravši svoju narativnu ulogu protivnika Pavlova evanđelja. ${ }^{58}$ Njegov je odgovor na njihov izazov čvrst i jasan: Tit se ne mora obrezati $(2,3)$, on i njegovi drugovi nisu popustili ni na trenutak $(2,5)$ jer su vidjeli kako ih lažna braća žele odvesti u ropstvo. U 2, 4 Pavao koristi prvo lice množine kako bi pokazao da bi zarobljavanje pogana jarmom Zakona i za židovske kršćane značilo povratak pod princip ropstva. ${ }^{59} \mathrm{U} 2,6$ pozornost svoje publike usmjerava na jeruzalemske apostole, koji do sada nisu imali aktivnu ulogu, i njiho-

\footnotetext{
${ }^{54}$ Usp. R. ADAMS, The Israel of God, 240.

${ }^{55}$ Usp. isto, 243.

${ }^{56}$ Usp. P. KOPTAK, Rhetorical Identification In Paul's Autobiographical Narrative, URL: http://www. religiononline.org/showarticle.asp?title=4 (27. II. 2014.)

${ }^{57}$ Usp. D. F. TOLMIE, A Rhetorical Analysis of The Letter to The Galatians, 74.

${ }^{58}$ Usp. R. ADAMS, The Israel of God, 245.

${ }^{59}$ Usp. P. KOPTAK, Rhetorical Identification In Paul's Autobiographical Narrative, URL: http://www. religiononline.org/showarticle.asp?title $=4$ (27. II. 2014.)
} 
vu reakciju na obranu evanđelja od napada lažne braće. Stupovi jeruzalemske zajednice uvidjeli su kako je Pavlu evanđelje za neobrezane povjerio $(\pi \varepsilon \pi i \sigma \tau \varepsilon v \mu a \iota)$ isti božanski autoritet koji je njima povjerio djelo među obrezanima. Riječ $\pi \varepsilon \pi i \sigma \tau \varepsilon v \mu a \iota$ čest je pavlovski izričaj i označava božanski izvor evanđelja. ${ }^{60}$

\subsection{Antiohijska epizoda naracije (Gal 2, 11-14)}

Posljednji odjeljak Pavlove pripovijesti uvodi podjelu između njega i Kefe. Kao njezin vrhunac, ova epizoda demonstrira kako se izdaju principi jedinstva kada ljudi temelje svoje postupke na ugađanju ljudima umjesto Bogu. Dok se raspada odnos između Kefe, Pavla i antiohijskih kršćana, Galaćani promatraju još jednu sliku onoga što leži pred njima ako se odluče obrezati. ${ }^{61}$ Između događaja u Jeruzalemu i Antiohiji nema narativnog prekida, samo se mijenja pozornica. Dok je Pavao u 2, 1 prešao iz pripovijesti svog životnog obrata u Jeruzalem, sažimajući četrnaest godina $\mathrm{u}$ jednu frazu, u 2, 11 nema indikacije prolaska vremena. Problemi u Antiohiji izbili su »odmah« nakon zajedništva uspostavljena u Jeruzalemu, tako naglašavajući kontrast događaja između dvije lokacije. ${ }^{62}$

Kakva god bila svrha i brojnost nekih koji su od Jakova došli u Antiohiju, njihova prisutnost navela je Kefu da napusti princip uključivosti koji je uspostavio blagujući s poganima. Pavao tumači njegove postupke kroz prizmu iste suprotnosti autoriteta koju uspostavlja kroz cijelu pripovijest. U strahu od onih iz obrezanja, Kefa je nastojao ugoditi njima umjesto Bogu. Podilaženje ljudskoj volji nauštrb božanske uvelo je razdor gdje je prije bilo jedinstvo. Iz Apostolove perspektive, Kefa čini istu stvar koju su lažna braća pokušala postići u Jeruzalemu (glagol za prisilu jednak je u 2, 3 i 2, 14). Za Galaćane to znači kako više neće biti Kristovi sluge ako odaberu obrezanje, nego će postati sluge onih koji od njih zahtijevaju da se obrežu. Živjeli bi kao što je Pavao živio svoj raniji život - ugađajući ljudima umjesto Bogu. ${ }^{63}$

U jedanaestom retku Pavao započinje kratki sumarij događaja u Antiohiji. Neko vrijeme nakon što su jeruzalemski autoriteti prepoznali izvor i sadržaj njegova evanđelja, Apostol je bio prisiljen usprotiviti se Kefi u lice jer je »zaslužio osudu «. Teško je odrediti točno značenje tih riječi u ovom slučaju, a postoji nekoliko mogućnosti. U svakom slučaju, jasno je kako koristi tu riječ da bi njegovo ponašanje

${ }^{60}$ Usp. D. F. TOLMIE, A Rhetorical Analysis of The Letter to The Galatians, 76.

${ }^{61}$ Usp. P. KOPTAK, Rhetorical Identification In Paul's Autobiographical Narrative, URL: http://www. religiononline.org/showarticle.asp?title=4 (27. II. 2014.)

${ }^{62}$ Usp. R. ADAMS, The Israel of God, 254.

${ }^{63}$ Usp. P. KOPTAK, Rhetorical Identification In Paul's Autobiographical Narrative, URL: http://www. religiononline.org/showarticle.asp?title=4 (27. II. 2014.) 
ocrtao u vrlo negativnom svijetlu. ${ }^{64}$ Vjernici iz židovstva, jednostavno označeni kao

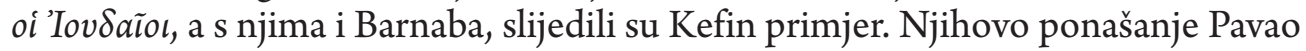

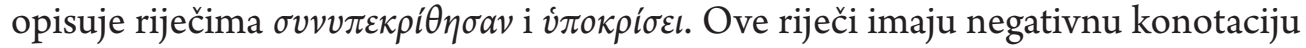
i koriste se za opisivanje radnji kojima ljudi ostavljaju dojam određenih motivacija i ciljeva, a zapravo smjeraju nešto drugo. Pavao kori Kefu jer, iako sam ne živi ži-

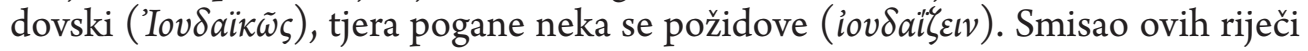
uglavnom je istovjetan, a označava osobu koja običava prakticirati židovske forme ponašanja. Tolmie smatra kako se $u$ ovom kontekstu najvjerojatnije radi o prisiljavanju nežidovskih vjernika Antiohije na sudjelovanje u zajedničkim obrocima pripremljenim po židovskim ritualnim propisima. ${ }^{65}$

Petnaesti redak označava kraj Pavlova narativnog prikaza događaja iz prošlosti i početak izravne argumentacije. Zbog ograničenosti prostora, demonstrativna sekcija i ostatak Poslanice Galaćanima bit će obrađeni u budućem članku.

\footnotetext{
${ }^{64}$ Usp. D. F. TOLMIE, A Rhetorical Analysis of The Letter to The Galatians, 84.

${ }^{65}$ Usp. isto, 87.
} 
- I. ČAtiĆ- M. Rajić, RetoričKo-KritičKa ANALiza Poslanice ..., STR. 567.-583.

\title{
THE RHETORICAL-CRITICAL ANALYSIS OF THE EPISTLE TO THE GALATIANS (I)
}

\author{
Ivica ČATIĆ ${ }^{*}-$ Marko RAJIĆ $* *$
}

Summary: The article analyses Paul's Epistle to the Galatians according to the principles of rhetorical criticism. This approach to biblical text has become prominent in the last four decades. Early adherents of this method worked under the assumption that Paul wrote in conformity with the then known manuals of rhetoric. To that effect, the introduction of the article questions the relationship between Paul's epistles and the ancient rhetoric and literary world. It also analyses the possibility of accepting a broader understanding of rhetoric offered by the modern study of the discipline. The introduction is concluded by the question of the relationship between rhetoric and epistolography, as well as the question of partition of the rhetorical act and its application to the Epistle to the Galatians. It is followed by the analysis of the main rhetorical elements of the Epistle to the Galatians, which will, due to the limited space, be continued in a future issue of this journal.

Keywords: Epistle to the Galatians, rhetoric, rhetorical criticism, epistolography.

\footnotetext{
* Assoc. Prof. Ivica Čatić, Ph. D., Catholic Faculty of Theology in Đakovo, J. J. Strossmayer University of Osijek, P. Preradovića 17, 31400 Đakovo, Croatia, ivicat6@gmail.com

** Marko Rajić, mag. theol., S. Radića 153, Gašinci, 31421 Satnica Đakovačka, Croatia, marko-rajic@ live.com
} 